\title{
ANALISIS PENGARUH FAKTOR SOSIAL, BUDAYA DAN TINGKAT PENGETAHUAN KOMUNITAS SAMIN TERHADAP PREFERENSI PERBANKAN SYARIAH DI KABUPATEN BOJONEGORO
}

(Analysis of The Influence of Social, Cultural Factors and Knowledge Levels Of Samin Community on Sharia Banking Preference in Bojonegoro Regency)

\section{R. Yudhistira Adi Seputra ${ }^{1}$, Happy Adianita ${ }^{2}$}

${ }^{1,2}$ Program Studi Ekonomi Pembangunan Fakultas Ekonomi Universitas Bojonegoro yudhiseputra81@gmail.com

\begin{tabular}{l}
\hline \hline Info Artikel (11 pt) \\
\hline Diterima Februai 1, 2021 \\
Direvisi Februari 20, 2021 \\
Dipublikasi Maret 20, \\
2021
\end{tabular}

Kata Kunci:

Keputusan Nasabah, Faktor Sosial, Faktor Budaya, Tingkat Pengetahuan, Preferensi, Perbankan Syariah

Keywords :

Tourist Experience, Revisit Intention, Dark Tourism

\begin{abstract}
Abstrak
Penelitian ini memeriksa pengaruh faktor Sosial Budaya dan tingkat pengetahuan yang mempengaruhi preferensi komunitas Samin terhadap Perbankan Syariah di Kabupaten Bojonegoro. Penelitian ini juga bertujuan untuk mengetahui faktor manakah yang mempengaruhi keputusan nasabah, dalam hal ini komunitas Samin di Bojonegoro, dalam memilih perbankan syariah dan faktor yang mendominasi. Penelitian ini merupakan penelitian kuantitatif dengan mengaplikasikan analisis regresi logistik (binary logistic regression). Subyek dalam penelitian ini merupakan komunitas adat samin yang bermukim di Kabupaten Bojonegoro. Rata-rata responden berusia yang masuk kategori usia produktif yaitu dari usia 15 hingga 55 tahun dengan jumlah 100 responden. Responden bukan merupakan nasabah bank Syari'ah.
\end{abstract}

\footnotetext{
Abstract

This study examines the influence of socio-cultural factors and the level of knowledge that affect the preferences of the Samin community towards Islamic banking in Bojonegoro Regency. This study also aims
} 


\title{
PENDAHULUAN
}

\begin{abstract}
to determine which factors influence customer decisions, in this case the Samin community in Bojonegoro, in choosing Islamic banking and the dominant factors. This research is a quantitative study by applying logistic regression analysis (binary logistic regression). The subjects in this study were the Samin traditional communities who live in Bojonegoro Regency. The average age of respondents who fall into the productive age category is from the age of 15 to 55 years with a total of 100 respondents. Respondents are not customers of Syari'ah banks.
\end{abstract}

Adanya bank syariah di antara dominasi perbankan konvensional merupakan sebuah penawaran sistem perbankan alternatif yang dinilai positif bagi masyarakat yang membutuhkan layanan jasa perbankan tanpa harus khawatir atas persoalan bunga (riba). Kembali pada tujuan didirikannya Bank syariah adalah untuk mempromosikan dan mengembangkan penerapan prinsip-prinsip Islam dan tradisinya ke dalam transaksi keuangan dan perbankan serta bisnis yang terkait. Data perbankan mencatat pada record bulan Februari 2012, industri perbankan syariah mampu menunjukkan percepatan pertumbuhan yang tinggi, rata-rata sebesar 40,2\% pertahun dalam lima tahun terakhir (2007- 2011), sementara rata-rata pertumbuhan perbankan nasional hanya sebesar $16,7 \%$ pertahun. Merujuk pada data tersebut, maka tepat apabila industri perbankan syariah dijuluki sebagai “The Fastest Growing Industry” (Alamsyah, 2012: 3). Pada tahun 19922016, data menunjukkan 12 BUS dengan jaringan individual dari masing-masing bank di seluruh penjuru Indonesia meningkat cukup signifikan. Melihat begitu pesatnya perkembangan Bank Syariah dan pentingnya fungsi serta peranan perbankan syariah, maka pihak bank syariah dinilai perlu meningkatkan kinerja keuangannya agar terwujud perbankan dengan prinsip syariah yang efisien, akuntabel dan sehat. Hal ini perlu terus dievaluasi karena kebangkrutan sektor perbankan bisa saja terjadi dan dapat disebabkan oleh kondisi atau kinerja perusahaan yang memburuk serta ketidakmampuan pemenuhan kewajiban.

Tercatat CAR Bank Muamalat masih mencukupi tapi mengalami trend penurunan dari tahun 2013-2017 puncaknya di tahun 2013-2014 sebesar 3.33\%. NPF juga tercatat 


\section{JURNAL

cukup tinggi dengan persentase $4.33 \%$ di akhir tahun 2016. Berdasarkan Analisa DEA tercatat Bank Muamalat dalam kondisi tidak efisien pada tahun 2014-2017. (Adiseputra, 2019)

Gambar 1

Bank Syariah di Indonesia

Dari Masa ke Masa

\begin{tabular}{|l|c|c|c|c|c|c|c|}
\hline \multicolumn{1}{|c|}{ Indikator } & 2011 & 2012 & 2013 & 2014 & $\begin{array}{c}\text { Mar } \\
2015\end{array}$ & $\begin{array}{c}\text { April } \\
2015\end{array}$ & $\begin{array}{c}\text { Juni } \\
2015\end{array}$ \\
\hline Jumlah Bank Umum Syariah & 11 & 11 & 11 & 12 & 12 & 12 & 12 \\
\hline $\begin{array}{l}\text { Jumlah UUS - BU } \\
\text { Konvensional }\end{array}$ & 24 & 24 & 23 & 22 & 22 & 22 & 22 \\
\hline Jumlah BPRS & 155 & 158 & 163 & 163 & 162 & 162 & 162 \\
\hline $\begin{array}{l}\text { Jumlah Jaringan Kantor (BUS } \\
\text { + UUS) }\end{array}$ & 1,737 & 2,262 & 2,588 & 2,517 & 2,463 & 2,458 & 2,448 \\
\hline Total Asset (Rp. Trilliun) & 145.47 & 195.02 & 242.28 & 272.34 & 268.36 & 269.47 & 273.49 \\
\hline Pertumbuhan Aset (yoy) & $49 \%$ & $34 \%$ & $24 \%$ & $12.41 \%$ & $11.39 \%$ & $10.35 \%$ & $8.57 \%$ \\
\hline Market Share & $3.98 \%$ & $4.58 \%$ & $4.89 \%$ & $4.85 \%$ & $4.68 \%$ & $4.69 \%$ & $4.61 \%$ \\
\hline DPK (Rp. Trilliun) & 115.41 & 147.51 & 183.53 & 217,86 & 212.99 & 213.97 & 213.48 \\
\hline Pembiayaan (Rp. Trilliun) & 102.66 & 147.51 & 184.12 & 199,30 & 200.71 & 201.53 & 206.06 \\
\hline NPF (gross) & $2.52 \%$ & $2.22 \%$ & $2.62 \%$ & $4.33 \%$ & $4.81 \%$ & $4.62 \%$ & $4.73 \%$ \\
\hline CAR & $16.63 \%$ & $14.13 \%$ & $14.44 \%$ & $16.10 \%$ & $13.85 \%$ & $14.06 \%$ & $14.09 \%$ \\
\hline FDR & $88.94 \%$ & $100.0 \%$ & $100.32 \%$ & $91.50 \%$ & $94.24 \%$ & $94.18 \%$ & $96.52 \%$ \\
\hline
\end{tabular}

Sumber: Departemen Perbankan Syariah Otoritas Jasa Keuangan

Berdasarkan Gambar I diatas dapat diketahui jumlah Bank Umum Syariah (BUS) tidak mengalami kenaikan yang cukup signifikan dari tahun 2011-2015 hanya mengalami kenaikan 1 BUS. Jumlah Jaringan Kantor (BUS+UUS) juga kecenderungan mengalami penurunan mulai tahun 2014 hingga 2015, dari sejumlah 2,588 menurun hingga 2,448 tercatat mengalami penurunan 140 jumlah jaringan kantor selama 2 tahun berturut-turut. Demikian pula Pertumbuhan Aset (yoy) yang terus mengalami penurunan yang cukup signifikan dari $49 \%$ hingga $8.57 \%$ dalam kurun waktu 3 tahun. Hal ini pun menyisakan pertanyaan yang cukup besar bagi sebagian besar peneliti maupun praktisi Keuangan Syariah tentang Sustainabilitas Keuangan Perbankan Syari'ah padahal di satu sisi Indonesia sebagai salah satu Negara berpenduduk mayoritas Muslim seharusnya memiliki potensi yang cukup besar untuk mengembangkan system keuangan berbasis Syari'ah. Ketatnya persaingan disinyalir menjadi salah satu tantangan yang cukup signifikan bagi perbankan di Indonesia. 
Kompetisi bisnis perbankan di Indonesia, merupakan hal menarik untuk diteliti. Bank-bank tersebut menyusun berbagai strategi bisnis, termasuk strategi marketing tertarget untuk mempengaruhi keputusan para nasabah dalam memilih produk perbankan. Kotler dan Keller (2009: 214) menyatakan bahwa perilaku pembelian konsumen dipengaruhi oleh faktor-faktor kekuatan budaya, sosial, pribadi dan psikologis.

Secara teori, ilmu ekonomi menyatakan, kebutuhan dan keinginan konsumen selalu berubah setiap saat. Demikian pula cara pandang konsumen terhadap suatu produk. Oleh sebab itu, sangatlah penting bagi pelaku perbankan untuk selalu memperhatikan dan mempelajari tentang perilaku konsumen. Tjiptono (2008:40) mengatakan, "perilaku konsumen merupakan pelaku yang ditunjukkan oleh konsumen dalam mencari, membeli, menggunakan mengevaluasi, dan menghentikan konsumsi produk, jasa, dan gagasan". Kotler (2002 1:183) berpendapat "perilaku pembelian konsumen dipengaruhi oleh faktor budaya, faktor sosial, faktor pribadi, dan faktor psikologis". Dengan demikian, jika dihubungkan dengan bidang perbankan syariah secara umum, pendapat Kotler tersebut memunculkan pertanyaan pada tataran aplikasi di lapangan pada komunitas-komunitas adat budaya tertentu; apakah keempat faktor itu berpengaruh dan seberapa besar pengaruhnya terhadap keputusan calon nasabah bank syariah khususnya bagi komunitas Samin di Kecamatan Margomulyo Kabupaten Bojonegoro. Mengingat komunitas Samin merupakan komunitas yang dapat dikatakan sebagai komunitas Islam 'abangan', yang tertutup terhadap kemajuan peradaban sebagai bentuk penolakan segala sistem warisan penjajah Belanda termasuk sistem Perbankan.

Masyarakat Samin adalah Komunitas adat yang menganut ajaran Saminisme. Ajaran Saminisme muncul karena reaksi terhadap pemerintah Kolonial Belanda yang sewenang-wenang terhadap orang-orang pribumi. Perlawanan mereka dilakukan bukan secara fisik, tetapi berwujud penentangan kepatuhan terhadap segala peraturan dan kewajiban yang harus dilakukan rakyat terhadap Belanda atau pemerintah dalam negeri, salah satunya yang cukup dikenal adalah dengan tidak membayar pajak. Terbawa oleh sikapnya yang menentang tersebut mereka membentuk tatanan, adat istiadat, dan kebiasaan tersendiri. Hal inilah yang mendasari dilakukannya penelitian ini, mengingat 


\section{JURNAL \\ ANALISIS, PREDIKSI, DAN INFORMASI}

bahwa produk dan sistem perbankan dapat dikatakan sebagai produk peninggalan Belanda yang bertentangan dengan prinsip saminisme dan sistem syariah yang masih belum banyak diketahui oleh komunitas Samin yang kebanyakan adalah pemeluk Islam 'abangan' atau kejawen sehingga menarik minat peneliti untuk menganalisis lebih dalam tentang ANALISIS PENGARUH FAKTOR SOSIAL, BUDAYA DAN TINGKAT PENGETAHUAN KOMUNITAS SAMIN TERHADAP PREFERENSI PERBANKAN SYARIAH DI KABUPATEN BOJONEGORO.

Penelitian ini akan menganalisis pengaruh faktor Sosial Budaya dan tingkat pengetahuan yang mempengaruhi preferensi komunitas Samin terhadap Perbankan Syariah di Kabupaten Bojonegoro. Penelitian ini juga bertujuan untuk mengetahui faktor manakah yang mempengaruhi keputusan nasabah, dalam hal ini komunitas Samin di Bojonegoro, dalam memilih perbankan syariah dan faktor mana yang lebih dominan serta mengamati perubahan budaya atau prinsip saminisme yang dianggap sejalan dengan konsep perbankan syariah. Penelitian ini juga bertujuan mengamati adanya perubahan dalam penerimaan atau penolakan sistem perbankan syariah pada sebuah komunal atau komunitas yang memegang teguh konsep budaya/sub-budaya tertentu.

Penelitian ini adalah penelitian kuantitatif dengan metode analisis data binary logistic regression atau lebih dikenal sebagai Regresi Logistik. Metode regresi ini digunakan dengan tujuan untuk mengukur perkiraan kebenaran model kategori (grup) dari sejumlah individu (Kuncoro, 2004:235). Subyek penelitian ini adalah komunitas adat samin yang bermukim di Kabupaten Bojonegoro berusia produktif muai dari 15 hingga 55 tahun. Responden berjumlah 100 orang. Responden adalah nasabah bank Konvensional.

Penelitian ini disusun sebagai berikut; Bagian 1 pendahuluan, Bagian 2 pertanyaan penelitian dan hipotesis, Bagian 3 mengulas tinjauan pustaka, Bagian 4 berfokus pada metodologi dan pengumpulan dan bagian data 5 temuan dan kesimpulan. 


\section{METODE PENELITIAN}

\section{Populasi dan Sampel}

Dalam penelitian ini Populasinya adalah seluruh komunitas samin di Kabupaten Bojonegoro. Sedangkan sampel penelitian ini adalah komunitas adat Samin di Kecamatan Margomulyo yang berusia produktif mulai dari usia 15 - 55 tahun sejumlah 100 responden dan bukan merupakan nasabah perbankan Syari'ah. Komunitas Adat Samin Jepang, bermukim di satu area permukiman komunitas Samin di Desa Margomulyo merupakan sampel penelitian ini, yang dipilih dengan cara Cluster Sampling berdasarkan Kecamatan. Sampel Kecamatan yang akan diamati berjumlah 1 Kecamatan yang berada di 1 Kabupaten yang sama, yaitu Kabupaten Bojonegoro yang berada di wilayah Provinsi Jawa Timur. Penentuan Kecamatan dilakukan secara purposive berdasarkan desa/padukuhan dimana lokasi Komunitas Samin tinggal. Desa Margomulyo merupakan satu dari enam desa yang berada di Kecamatan Margomulyo, Kabupaten Bojonegoro, Jawa Timur. Informasi dari pemerintahan setempat, Desa Margomulyo terdiri dari delapan dusun, yaitu Dusun Kalimojo, Jerukgulung, Tepus, Jatiroto, Batang, Kaligede, Ngasem, dan Dusun Jepang. Dusun Jepang inilah merupakan lokasi pemukiman komunitas masyarakat Adat Samin dan menjadi lokasi penelitian. Dusun Jepang ini terletak di sebelah Barat laut Desa Margomulyo, kurang lebih 4,5 km dari jalan raya, dan $5 \mathrm{~km}$ dari ibukota desa atau kecamatan, serta $70 \mathrm{~km}$ dari ibukota kabupaten. Batas wilayah Dusun Jepang di sebelah utara berbatasan dengan Dusun Batang, sebelah timur berbatasan dengan Dusun Kaligede, sebelah selatan Dusun Jatiroto, dan barat berbatasan dengan Desa Kalangan.

\section{Data}

Data dalam penelitian ini berupa data primer dan sekunder.

1. Data primer diperoleh dari pengisian kuesioner sesuai dengan jumlah sampel yang ditentukan dan data tabulasi berdasarkan hasil wawancara langsung dengan narasumber

2. Data sekunder berdasarkan studi literatur berupa; majalah, jurnal, surat kabar dan lain-lain. 


\section{JURNA A \\ ANALISIS, PREDIKSI, DAN INFORMASI}

\section{Teknik Analisa Data}

Uji Validitas dan Reliabilitas Kuesioner

Uji validitas digunakan untuk mengukur sah atau valid tidaknya suatu kuesioner (Ghozali, 2001, dalam Endang \& Laily, 2017). Uji signifikansi dilakukan dengan membandingkan nilai $\mathrm{r}$ hitung (nilai Corrected item-Total Correlation pada output Cronbach alpha) dengan nilai $\mathrm{r}$ tabel untuk degre of freedom $(\mathrm{df})=\mathrm{n}-2$ ( $\mathrm{n}$ adalah jumlah sampel). Ghozali (2012: 333)

Uji realibilitas dilakukan terhadap item pertanyaan yang dinyatakan valid. Uji ini digunakan untuk mengukur suatu kuesioner yang merupakan indikator dari variabel atau konstruk (Ghozali, 2001, dalam Endang \& Laily, 2017). Suatu kuesioner dikatakan reliabel atau handal jika jawaban seseorang terhadap pernyataan adalah konsisten atau stabil dari waktu ke waktu. Suatu variabel dikatakan reliabel jika memiliki Cronbach Alpha > 0,60 (Ghozali, 2001, dalam Endang \& Laily, 2017).

Statistika uji regresi logistik, digunakan untuk memprediksi probabilitas kejadian suatu peristiwa dengan cara mencocokkan data pada fungsi logit kurva logistik. Metode ini adalah salah satu model linier umum yang digunakan untuk regresi binomial. Metode ini menggunakan beberapa variabel prediktor, baik numerik maupun kategori.

Pada umumnya, rata-rata penelitian menggunakan tingkat signifikansi 1\%, 5\%, atau $10 \%$. Pada sebuah pengujian hipotesis jika menggunakan $\alpha=5 \%$, berarti peneliti memiliki keyakinan bahwa dari 100\% sampel, probabilitas anggota sampel yang tidak memiliki karakteristik populasi adalah 5\%. Berdasarkan teori yang telah diapaparkan di atas, maka pengujian ini dilakukan dengan menggunakan tingkat signifikansi $0,05(\alpha=$ 5\%). Ketentuan penolakan atau penerimaan hipotesis adalah sebagai berikut: Jika nilai signifikansi $<0,05$ maka hipotesis diterima (koefisien regresi signifikan). Ini berarti variabel independen mempunyai pengaruh yang signifikan terhadap variabel dependen. Jika nilai signifikansi > 0,05 maka hipotesis ditolak (koefisien regresi tidak signifikan). Ini berarti bahwa variabel independen tidak mempunyai pengaruh yang signifikan terhadap variabel dependen. 
Pengujian signifikansi pada regresi logistik dapat dibagi menjadi dua yaitu pengujian secara simultan dan pengujian secara parsial. Pengujian secara individual atau parsial dapat dilakukan dengan Uji Wald. Sedangkan pengujian secara simultan atau serentak dilakukan dengan menggunakan Uji Overal Model Fit/Omnibus.

Menilai Keseluruhan Model (Overall Model Fit)

Uji statistika ini untuk mengetahui apakah semua variabel independen di dalam regresi logistic secara serentak atau simultan mempengaruhi variabel dependen sebagaimana uji $\mathrm{F}$ di dalam regresi linier. Uji overall model fit didasarkan pada nilai statistika -2LL atau nilai LR. Uji serentak koefisien regresi model logistik dihitung dari perbedaan nilai -2LL antara model dengan hanya terdiri dari konstanta dan model yang diestimasi terdiri dari konstanta dan variabel independen (Widarjono, 2010: 141).

Pengujian dilakukan dengan membandingkan selisih nilai -2 log likehood (disebut dengan chi square hitung) dimana apabila nilai chi square hitung lebih besar dari chi square tabel atau nilai signifikansi lebih kecil dari alpha maka dapat dikatakan bahwa terdapat pengaruh secara simultan variabel bebas terhadap variabel terikat.

\section{Uji Wald}

Menurut Widarjono (2010: 123), dalam regresi logistik uji Wald digunakan untuk menguji ada tidaknya pengaruh dari variabel bebas terhadap variabel terikat secara parsial dengan cara membandingkan nilai statistik Wald dengan nilai pembanding Chi square pada derajat bebas $(\mathrm{db})=1$ pada alpha $5 \%$, atau dengan membandingkan nilai signifikansi (p- value) dengan alpha sebesar 5\% dimana p-value yang lebih kecil dari alpha menunjukkan bahwa hipotesis diterima atau terdapat pengaruh yang signifikan dari variabel bebas terhadap variabel terikat secara parsial.

Untuk meprediksi nilai variabel-variabel dependen maupun independen, penelitian ini mengaplikasikan Analisis Regresi Logistik untuk melihat preferensi Masyarakat Adat Komunitas Samin terhadap Bank Syariah dengan regresi sebagai berikut. 


\section{JURNAAL \\ ANALISIS, PREDIKSI, DAN INFORMASI}

$\mathrm{PREF}=\beta 0+\beta 1 \mathrm{SOC}+\beta 2 \mathrm{CULT}+\beta 3 \mathrm{KNOW}+\varepsilon$

Keterangan :

PREF = Preferensi Masyarakat (Keputusan Pilihan Komunitas Adat Samin terhadap bank syari'ah $=1$ dan pilihan komunitas adat samin terhadap Bank konvensional $=0$ )

SOC $=$ Faktor Sosial

CULT $=$ Faktor Budaya

KNOW $=$ Tingkat Pengetahuan

$\beta 0$

$=$ Bilangan konstanta

$\beta 1, \beta 2, \beta 3=$ Koefisien $($ Regresi)

$\varepsilon \quad=$ disturbance (error)

\section{Uji Hipotesis}

Pengujian hipotesis dilakukan dengan menggunakan nilai Wald untuk memastikan variabel-variabel dalam penelitian ini (Faktor Sosial, Faktor Budaya dan Tingkat Pengetahuan) memiliki pengaruh signifikan terhadap variabel dependen (Preferensi Komunitas Adat Samin). Adapun langkah-langkah pengujian dalam analisis ini adalah sebagai berikut:

a. Menentukan hipotesis

Ho : bi $=0$, variabel independen tidak mempengaruhi variabel dependen

$\mathrm{Ha}: \mathrm{bi} \neq 0$, variabel independen mempengaruhi variabel dependen

b. Menentukan daerah kritis menggunakan kriteria berdasarkan kemaknaan (significant) statistik, yaitu dengan p-value (nilai Sig.) lebih kecil dari $\alpha$ yang digunakan yakni 0,05 .

c. tingkat signifikansi $(\alpha)$ tertentu, dalam penelitian ini $\alpha$ adalah sebesar 5\%.

d. Pengambilan keputusan

Jika $p$-value (nilai Sig.) $<5 \%$ maka $\mathrm{H}_{0}$ ditolak

Jika $p$-value (nilai Sig.) > 5\% maka $\mathrm{H}_{0}$ diterima. 


\section{HASIL DAN PEMBAHASAN}

\section{Masyarakat Samin di Bojonegoro}

Bojonegoro adalah Kabupaten yang terlatak di Provinsi Jawa Timur yang berbatasan dengan Kabupaten: Lamongan ( di sebelah timur), Tuban (di sebelah utara), Nganjuk, Madiun, (di sebelah selatan), dan Kabupaten Blora Jawa Tengah (di sebelah barat). Di bagian sepanjang utara Kabupaten Bojonegoro merupakan wilayah pengairan Bengawan Solo yang subur dengan pertanian. Wilayah tersebut adalah Daerah Aliran Sungai (DAS). Margomulyo terletak dibagian Selatan Bojonegoro, tepatnya di lereng pegunungan Kendeng inilah tempat hidup masyarakat Samin, tepatnya di Dusun Jepang, Desa Margomulyo, Kecamatan Margomulyo. (Munawaroh et al, 2015)

Masyarakat Samin adalah Komunitas adat budaya yang menganut ajaran Saminisme. Ajaran ini dicetuskan oleh Samin Surosentiko yang lahir pada tahun pada tahun 1859 di Desa Ploso Kedhiren, Klopodhuwur, Randublatung, Blora. Ajaran Saminisme merupakan reaksi terhadap pemerintah Kolonial Belanda yang bersikap sewenang-wenang terhadap orang-orang pribumi. Perlawanan mereka dilakukan tidak secara fisik, tetapi berwujud ideology pertentangan terhadap segala peraturan dan kewajiban yang harus dilakukan rakyat terhadap pemerintahan Belanda saat itu, termasuk menolak membayar pajak lagi (Rosyid, 2010).

Masyarakat Samin memiliki kepribadian yang lugu dan jujur. Mereka selalu bersikap terbuka kepada siapa pun, termasuk kepada orang- orang yang belum dikenalnya. Mereka menganggap setiap orang sebagai saudara sehingga sikap kebersamaan selalu diutamakan. Sifat jujur dan terbuka tercermin dari perilaku, sikap maupun bahasa yang digunakan. Segala sesuatu yang dilakukan tidak pernah direkayasa. Jujur merupakan wujud sifat masyarakat Samin dari ajaran yang dianutnya (Mumfangati, dkk, 2004).

Dulu Komunitas adat samin kurang terbuka dengan Msayarakat luar. Namun dengan hadirnya teknologi memudahkan mereka mendapatkan pengalaman berinteraksi 


\section{JURNAL \\ ANALISIS, PREDIKSI, DAN INFORMASI}

dengan dunia luar. Saat ini, masyarakat Samin di Dusun Jepang mulai terbuka dengan masyarakat luar. Hal ini karena pengenalan teknologi dan kemudahan akses menuju Dusun Jepang. Jalan sudah dipaving dan telah diaspal. Hal ini semakin mempermudah akses bagi masyarakat Samin dan masyarakat luar untuk saling berinteraksi. Permukiman masyarakat Samin berada di tengah hutan, namun jaringan komputer, handphone, telepon, peralatan elektronik dan listrik dapat dengan mudah diakses. Sejak tahun 1990-an, masyarakat Samin mampu beradaptasi dengan segala perubahan yang ada. Berdirinya Sekolah Dasar/SD yang berada di Dusun Jepang merupakan awal mula masyarakat Samin mengenyam pendidikan, sehingga pendidikan menjadi kebutuhan penting bagi mereka. Bahkan sampai sekarang banyak warga komunitas adat Samin yang telah mengenyam pendidikan (bersekolah) hingga S2, menjadi PNS, polisi, petugas kesehatan, bidan dan sebagainya (Kompas, 2005:32). Hal menarik dari sikap masyarakat Samin saat ini adalah walaupun mereka telah 'membuka diri' dengan 'dunia luar', namun mereka tetap berpegang teguh terhadap ajarannya, yakni ajaran Saminis berasal dari leluhurnya, yaitu dengan tetap menjunjung tinggi kejujuran, toleransi, kebersamaan dan kegotongroyongan (masih tetap mempertahankan tradisi yang ada).

\section{Ekonomi Samin}

Komunitas Adat Samin memiliki bentuk ekonominya sendiri yang sering disebut sebagai “Ekonomi Samin”. Sistem ekonomi Samin adalah kebalikan mutlak dari sistem kapitalisme yang berorientasi pada keuntungan serta riba. Istilah kaya semakin kaya dan si miskin semakin miskin tidak berlaku untuk Samin. Perekonomian di Komunitas Adat Samin yang anti riba merupakan prinsip wajib di masyarakat Samin, hal ini tercermin dari pitutur atau petuah sesepuh sebagai berikut. "Nulung iku ora menthung" yang berarti Menolong itu tanpa pamrih bukan justru malah merugikan atau membuat orang lain lebih susah. Seperti sistem peminjaman uang atau pembiayaan di bank dengan bunga itu menurut orang Samin bertentangan dengan prinsip Samin. Logikanya orang cari pinjaman itu karena kesusahan tidak punya uang, dapat pinjaman tapi diwajibkan pengembalian dana dengan dibebankan tambahan biaya lagi itu bukan menolong tapi membuat orang lain menjadi lebih susah. Dari uraian di atas, sistem ekonomi Samin sejalan dengan ekonomi Islam yang kita semua pahami dengan baik. Ilmu ekonomi Islam 
adalah ilmu ekonomi yang diciptakan dengan sendi dan fondasi ajaran Islam; Teori dan model ekonomi Islam adalah teori dan model ekonomi yang terstruktur dan dibentuk berdasarkan ajaran Islam; Kebijakan ekonomi Islam adalah kebijakan ekonomi yang Islami; dirancang dan dilaksanakan dengan cara yang masuk akal dan Islami; yaitu kehidupan yang perekonomiannya dijalankan berdasarkan ilmu pengetahuan, teori, dan kebijakan yang bernilai keislaman. (Dumairy dalam Muhammad, 2005: 160)

Di Dukuh Jepang, Komunitas Adat Samin memiliki arisan tradisional yang merupakan wujud dari keberadaan nilai-nilai kearifan lokal yang diturunkan secara turuntemurun yang disebut dengan Arisan Gotong Royong. Tujuan utama diadakannya silaturahmi rutin ini adalah untuk mempererat persaudaraan keluarga Samin di desa Jepang dan untuk mengadakan kegiatan simpan pinjam tanpa bunga dengan batas waktu yang tidak mengikat, hanya berdasarkan prinsip kejujuran dan saling percaya. Kegiatan ini sangat bermanfaat ketika musibah datang dan menuntut adanya dana tunai untuk membantu biaya pengobatan misalnya. Kegiatan silaturahmi rutin ini dilakukan secara rutin pada hari Jumat. Jumlah uang yang digunakan untuk arisan adalah Rp10.000,- per orang.Untuk tabungan gotong royong tidak wajib hanya bagi yang ingin menabung untuk diambil mendekati Lebaran atau tabungan sisa dana penjualan hasil panen.

Temu sosial paling terkenal di kalangan Samin adalah gotong royong. Itu dilakukan setiap malam pada hari Jumat. Tujuan utama diadakannya arisan ini adalah untuk membantu sesama yang bermasalah dengan keuangan dengan cara meminjamkan uang tersebut. Sistem arisan ini adalah setiap warga negara yang mengikuti arisan wajib berkumpul pada malam Jumat. Kemudian mereka mengumpulkan sejumlah uang yang diyakini sebagai tabungan mereka.

Uang yang sudah disetorkan akan dicatat di buku dan bagi orang yang menabung akan diberikan tanda terima sederhana sebagai bukti. Uang yang disimpan oleh semua anggota arisan akan dijumlahkan dan pengurus akan memberikan kesempatan kepada setiap anggota arisan untuk mengungkapkan kesulitannya dan meminjam uang sejumlah dengan dana yang cukup untuk meminjamkannya. Uang yang dipinjam harus dikembalikan ke arisan berikutnya dengan jumlah yang sama; tidak kurang atau lebih. 


\section{JURNAL \\ ANALISIS, PREDIKSI, DAN INFORMASI}

Komunitas Adat Samin tidak menjadikan uang sebagai patokan dalam segala hal. Uang bukanlah hal yang mutlak yang menjadikan mereka seperti serigala yang haus akan mangsa, uang hanyalah sebagai pelengkap dalam perekonomian dunia bukan sebagai dewa dari segala sumber kebahagiaan. Berdasarkan uraian di atas, mendewakan uang seperti kaum kapitalis bukanlah hakikat Samin. Prinsip saduluran membuat mereka tidak mengenal riba. Ketika meminjamkan uang, tidak akan ada bunga yang berbeda dengan sistem kapitalis saat ini. Keyakinan mereka adalah membantu orang lain agar tidak memperkaya diri sendiri. Mereka mengedepankan persaudaraan dari pada uang karena nilai-nilai persaudaraan lebih mulia dari pada uang . Prinsip ini kemudian diterapkan dalam arisan gotong royong dengan semboyan mutlak tanpa bunga.

Penyelenggaraan arisan di Komunitas Adat Samin bebas dari sentuhan kapitalis yang identik dengan riba. Tradisi gotong royong ini mirip dengan prinsip mudharabah mutlaqah dalam keuangan syariah. Yang berbentuk tabungan dan deposito seperti deposito mudharabah dan mudharabah. Berdasarkan prinsip ini, tidak ada batasan bagi bank untuk menggunakan dana yang dihimpun. (Muhammad, 2007: 179). Gotong royong arisan memenuhi syarat dalam perjanjian deposito baik tabungan maupun deposito. Dikatakan menabung mudharabah karena dalam sistem pengumpulan gotong-royong, uang simpanan dapat diambil kapan saja sesuai dengan kebutuhan pemilik dana. Kemudian kata simpanan nasabah mudah karena jumlah yang tertera di kwitansi dan catatannya akan diterima sepenuhnya oleh anggota arisan saat pembongkaran arisan menjelang hari raya Idul Fitri. Sehingga tanpa disadari pihak Samin telah melakukan prektek pengelolaan keuangan syariah berupa dana simpan pinjam dalam sistem arisan gotong royong yang selama ini berlangsung.

Komunitas Adat Samin telah melakukan ekonomi Islam meskipun mereka sama sekali tidak mengetahuinya. Ini membuktikan bahwa Islam adalah "RahmatanLil "Alamin" dan begitu mudah diterima di kalangan masyarakat. Sistem Islam dapat merangkul siapa pun dengan menyelinap secara halus ke persendian komunitas untuk menciptakan harmoni yang nyata. Budaya Samin yang kuat juga telah merasakan humanisnya sistem Keuangan Islam meski mereka tidak menyadarinya. Samin telah menyadarkan kita bahwa hidup itu sesingkat jeda antara Adzan dan Iqomah, sehingga 
kita hendaknya menjadikan kebaikan sebagain landasan dan tujuan hidup, seperti misi abadi Samin yaitu "mencari air yang jernih" yang berarti mencari kebaikan di dunia dan kehidupan setelahnya.

\section{Uji Kualitas Data}

Hasil uji validitas dan reliabilitas pertanyaan kuesioner menentukan kualitas dan instrumen penelitian, sehingga uji validitas dan reliabilitas terhadap instrumen penelitian diperlukan. Cooper dan Emory (1995) menyatakan bahwa suatu data penelitian tidak akan berguna apabila instrumen pengukuran yang digunakan tidak memiliki tingkat validitas dan reliabiltas yang tinggi.

a. Uji Validitas

Hasil pengujian validitas dari masing-masing item pada variabel-variabel; Sosial (SOC), Budaya (CULT) dan Tingkat Pengetahuan (KNOW), menunjukan seluruh butir pernyataan yang dipergunakan dalam penelitian ternyata valid karena nilai $r$ hitung semua lebih besar dari nilai $r$ tabel yakni sebesar 0,165 .

Tabel 1 Koefisien Validitas Variabel Performance

\begin{tabular}{|c|c|c|c|}
\hline No. & Butir & rhitung & Kesimpulan \\
\hline \multicolumn{4}{|c|}{ Faktor Sosial $($ SOC) } \\
\hline 1 & SOC1 & 0,438 & Valid \\
\hline 2 & SOC2 & 0,497 & Valid \\
\hline 3 & SOC3 & 0,591 & Valid \\
\hline 4 & SOC4 & 0,524 & Valid \\
\hline 5 & SOC5 & 0,508 & Valid \\
\hline 6 & SOC6 & 0,556 & Valid \\
\hline 7 & SOC7 & 0,595 & Valid \\
\hline Faktor Budaya (CULT) \\
\hline 1 & CULT1 & 0,722 & Valid \\
\hline 2 & CULT2 & 0,624 & Valid \\
\hline
\end{tabular}




\section{JURNAL ERBIS \\ ANALISIS, PREDIKSI, DAN INFORMASI} Csintà

Sumber : Data primer (diolah), 2020

\begin{tabular}{|c|c|c|c|}
\hline 3 & CULT3 & 0,729 & Valid \\
\hline 4 & CULT4 & 0,531 & Valid \\
\hline 5 & CULT5 & 0,739 & Valid \\
\hline 6 & CULT6 & 0,778 & Valid \\
\hline 7 & CULT7 & 0,456 & Valid \\
\hline
\end{tabular}

Tingkat Pengetahuan (KNOW)

\begin{tabular}{|c|c|c|c|}
\hline 1 & KNOW1 & 0,667 & Valid \\
\hline 2 & KNOW2 & 0,826 & Valid \\
\hline 3 & KNOW3 & 0,835 & Valid \\
\hline 4 & KNOW4 & 0,861 & Valid \\
\hline 5 & KNOW5 & 0,835 & Valid \\
\hline 6 & KNOW6 & 0,788 & Valid \\
\hline 7 & KNOW7 & 0,689 & Valid \\
\hline 8 & KNOW8 & 0,319 & Valid \\
\hline
\end{tabular}

b. Uji Reliabilitas

Ukuran koefisien cronbach's alpha antara 0 hingga 1, makin besar nilai koefisien cronbach's alpha semakin tinggi keandalan alat ukur yang digunakan. Reliabilitas cronbach's alpha mencapai angka 0,6 secara umum dapat diterima, dan lebih dari 0,7 dianggap baik (V. Wiratna Sujarweni, 2015). Pengujian reliabilitas dengan menggunakan rumus sebagai berikut:

$$
\mathrm{r}=\frac{\mathrm{k}}{(\mathrm{k}-1)}\left[1-\frac{\sum \sigma \mathrm{b}^{2}}{\sigma \mathrm{t}^{2}}\right]
$$

Keterangan:

$\mathrm{r} \quad=$ Reliabilitas instrumen

$\mathrm{K}$ = Banyak butir pertanyaan

$\sigma \mathrm{t}^{2}=$ Jumlah varian total

$\Sigma \sigma b^{2}=$ Jumlah varian butir 
Untuk memproses analisis data tersebut, penelitian ini memanfaatkan piranti lunak (program) SPSS ${ }^{\text {TM }}$ (Mendenhall \& Beaver,1992). Adapun hasil uji kualitas data tersebut adalah sebagai berikut:

Tabel 2

Reliabilitas Atribut

\begin{tabular}{|c|l|c|c|}
\hline No. & \multicolumn{1}{|c|}{ Atribut } & Cronbach's Alpha & Kesimpulan \\
\hline 1 & Faktor Sosial & 0,795 & Reliabel \\
\hline 2 & Faktor Budaya & 0,870 & Reliabel \\
\hline 3 & Tingkat Pengetahuan & 0,912 & Reliabel \\
\hline
\end{tabular}

Sumber: Data diolah

Kuesioner yang didistribusikan sebanyak 100 dalam penelitian ini. Kuesionerkuesioner tersebut dibagikan kepada komunitas Adat Samin yang merupakan Nasabah non Syariah atau nasabah bank konvensional. Tabel 4.3 menunjukkan secara ringkas jumlah sampel dan tingkat pengembalian kuesioner dari hasil pengumpulan data responden.

\section{Tabel 3}

Jumlah Sampel dan Pengembalian Kuesioner

\begin{tabular}{|l|c|}
\hline \multicolumn{1}{|c|}{ Keterangan } & Jumlah \\
\hline Total kuesioner & 100 \\
Jumlah Kuesioner Kembali & 100 \\
Jumlah Kuesioner tidak kembali & 0 \\
Total kuesioner yang tidak dapat & 0 \\
diolah & 100 \\
& \\
\hline
\end{tabular}

Sumber: Data Primer(diolah), 2020 


\section{JURNAL

\section{Statistik Deskriptif}

Hasil analisa statistik deskriptif responden dalam penelitian ini adalah:

Tabel 4

Pendidikan Responden

\begin{tabular}{|c|c|c|}
\hline Tingkat Pendidikan & Frekuensi & Persen \\
\hline SMU & 56 & 56,0 \\
\hline DIPLOMA & 10 & 10,0 \\
\hline S1 & 31 & 31,0 \\
\hline S2 & 3 & 3,0 \\
\hline Total & 100 & 100,0 \\
\hline
\end{tabular}

Sumber: Data Primer (diolah) 2020

Tingkat Pendidikan Responden Komunitas Adat Samin cukup bervariasi mulai dari tingkat SMU, Diploma, Sarjana dan Pasca Sarjana. Responden berlatar pendidikan SMU sejumlah 56 orang atau diprosentase sebesar (56\%). Disusul responden bergelar Sarjana berjumlah 31 orang (31\%). Jumlah responden dengan tingkat pendidikan Diploma berjumlah 10 orang (10\%), dan responden yang bergelar Sarjana Strata Dua berjumlah 2 orang (2\%). Menurut tabel di atas dapat diketahui responden dengan tingkat pendidikan banyak SMU sebesar 56\% dan bergelar Sarjana sebesar 31\%.

Tabel 5

Usia Responden

\begin{tabular}{|l|c|c|}
\hline Variabel Umur & Frekuensi & Persen \\
\hline 15-25 tahun & 8 & 8,0 \\
\hline 25-30 tahun & 12 & 12,0 \\
\hline 30-35 tahun & 15 & 15,0 \\
\hline 35-40 tahun & 45 & 45,0 \\
\hline 40-45 tahun & 10 & 10,0 \\
\hline
\end{tabular}




\begin{tabular}{|l|c|c|}
\hline $45-50$ tahun & 7 & 7,0 \\
\hline$>50$ tahun & 3 & 3,0 \\
\hline Total & 100 & 100,0 \\
\hline
\end{tabular}

Sumber: Data Primer (diolah), 2020

\section{Pengaruh Faktor Sosial, Faktor Budaya dan Tingkat Pengetahuan Komunitas Adat} Samin Terhadap Preferensi Perbankan Syariah di Kabupaten Bojonegoro

Setelah dilakukan pengolahan data maka diperoleh hasil regresi seperti yang tersaji dalam tabel 4.4 .

Tabel 6

Ringkasan hasil regresi logistik

Variables in the Equation

\begin{tabular}{|l|r|r|r|r|r|r|}
\hline & \multicolumn{1}{|c|}{ B } & S.E. & Wald & df & Sig. & $\operatorname{Exp}(\mathrm{B})$ \\
\hline Step $1^{\text {a }}$ SOC & 1.492 & .555 & 7.231 & 1 & .007 & 4.446 \\
CULT & .023 & .635 & .001 & 1 & .971 & 1.024 \\
KNOW & .364 & .426 & .730 & 1 & .393 & 1.440 \\
Constant & -5.276 & 3.015 & 3.062 & 1 & .080 & .005 \\
\hline
\end{tabular}

a. Variable(s) entered on step 1: SOC, CULT, KNOW.

Apabila hasil regresi pada tabel 4.4 di atas ditulis dalam persamaan regresi menjadi:

$\mathrm{PREF}=-5.276+1.492 \mathrm{SOC}+0.023 \mathrm{CULT}+0.364 \mathrm{KNOW}$

$$
\begin{array}{llll}
(3.062) & (7.231) \quad(0.001) \quad(0.730)
\end{array}
$$

$\begin{array}{lllll}\text { Sig. } & 0.080 & 0.007 & 0.971 & 0.393\end{array}$

Keterangan :

SOC adalah variabel Sosial

CULT adalah variabel Budaya

KNOW adalah variabel Pengetahuan

PREF adalah variabel preferensi masyarakat 


\section{JURNAL

Nilai dalam kurung adalah nilai Wald.

Berdasarkan tabel 4.6 dan persamaan regresi di atas dapat diketahui bahwa hasil analisis multivariat ternyata ketiga variabel (SOC, CULT, KNOW) berpengaruh positif terhadap preferensi bank Syari'ah Komunitas Adat Samin di Kabupaten Bojonegoro. Namun hanya variable (SOC) yang menunjukkan pengaruh signifikan dengan nilai $p$ value 0.007 dan mempunyai odds ratio 4.446 lebih besar dari 1,00.

\section{Pengaruh (SOC) Faktor Sosial Komunitas Adat Samin Terhadap Preferensi Perbankan Syariah di Kabupaten Bojonegoro}

Uji hipotesis penelitian Faktor Sosial Komunitas Adat Samin tidak berpengaruh pada probabilitas Preferensi Perbankan Syariah di Kabupaten Bojonegoro dengan menggunakan analisis regresi logistik adalah:

$\mathrm{H}_{0}$ : Faktor Sosial Komunitas Samin tidak berpengaruh pada probabilitas Preferensi Perbankan Syariah di Kabupaten Bojonegoro.

$\mathrm{H}_{\mathrm{a}}$ : Faktor Sosial Komunitas Samin berpengaruh pada probabilitas Preferensi Perbankan Syariah di Kabupaten Bojonegoro.

Berdasarkan hasil regresi logistik diketahui bahwa variabel Sosial (SOC) berpengaruh positif dan signifikan terhadap probabilitas Preferensi Perbankan Syariah Komunitas Adat Samin di Kabupaten Bojonegoro (PREF) dengan nilai variabel (SOC) sebesar 0.007 lebih kecil dari $\alpha=5 \%$. Hal ini menunjukkan bahwa variabel (SOC) mempunyai pengaruh positif dan signifikan yerhadap Preferensi bank Syari'ah. Komunitas Adat Samin Kabupaten Bojonegoro.

\section{Pengaruh (CULT) Faktor Budaya Komunitas Adat Samin Terhadap Preferensi Perbankan Syariah di Kabupaten Bojonegoro}

Pengaruh Faktor Budaya (CULT) terhadap Preferensi Perbankan Syariah Komunitas Adat Samin di Kabupaten Bojonegoro, uji hipotesisnya adalah sebagai berikut: 


\section{JURNALL

$\mathrm{H}_{0}$ : Faktor Budaya (CULT) Komunitas Samin tidak berpengaruh pada probabilitas

Preferensi Perbankan Syariah di Kabupaten Bojonegoro.

$\mathrm{H}_{\mathrm{a}}$ : Faktor Budaya (CULT) Komunitas Samin berpengaruh pada probabilitas

Preferensi Perbankan Syariah di Kabupaten Bojonegoro.

Sesuai hasil regresi juga diketahui bahwa variabel Budaya (CULT) berpengaruh positif namun tidak signifikan terhadap Preferensi Perbankan Syariah di Kabupaten Bojonegoro (PREF) dengan nilai variabel Budaya (CULT) sebesar 0.971 lebih besar dari $\alpha=5 \%$, sehingga $\mathrm{H}_{\mathrm{a}}$ ditolak atau $\mathrm{H}_{0}$ diterima.

Nilai beta variabel Budaya (CULT) sebesar 0.364 dengan koefisien arah positif. Hal ini berarti jika Faktor Budaya (CULT) meningkat maka probabilitas Preferensi Perbankan Syariah di Kabupaten Bojonegoro juga akan meningkat, begitu pula sebaliknya.

\section{Pengaruh (KNOW) Tingkat Pengetahuan Komunitas Adat Samin Terhadap Preferensi Perbankan Syariah di Kabupaten Bojonegoro}

Pengaruh Faktor Tingkat Pengetahuan (KNOW) Komunitas Adat Samin Kabupaten Bojonegoro Terhadap Preferensi Perbankan Syariah, uji hipotesisnya adalah sebagai berikut:

$\mathrm{H}_{0}$ : Faktor Tingkat Pengetahuan (KNOW) Komunitas Samin tidak berpengaruh pada probabilitas Preferensi Perbankan Syariah di Kabupaten Bojonegoro.

$\mathrm{H}_{\mathrm{a}}$ : Faktor Tingkat Pengetahuan (KNOW) Komunitas Samin berpengaruh pada probabilitas Preferensi Perbankan Syariah di Kabupaten Bojonegoro.

Hasil regresi menunjukkan variabel Faktor Tingkat Pengetahuan (KNOW) berpengaruh positif namun tidak signifikan terhadap Preferensi Perbankan Syariah Komunitas Adat Samin di Kabupaten Bojonegoro (PREF). Hal ini ditunjukkan oleh nilai variabel Tingkat Pengetahuan (KNOW) sebesar 0.393 lebih besar dari $\alpha=5 \%$, sehingga $\mathrm{H}_{\mathrm{a}}$ ditolak atau $\mathrm{H}_{0}$ diterima. 


\section{JURNAL \\ ANALISIS, PREDIKSI, DAN INFORMASI}

Nilai beta pada variabel Tingkat Pengetahuan (KNOW) adalah 0.023 dengan koefisien arah positif. Hal ini berarti jika Faktor Tingkat Pengetahuan (KNOW) meningkat maka Preferensi Perbankan Syariah Komunitas Adat Samin di Kabupaten Bojonegoro juga meningkat.

\section{Pembahasan}

Berdasarkan hasil regresi menunjukkan ketiga variabel (SOC, CULT, KNOW) berpengaruh positif terhadap preferensi bank Syari'ah Komunitas Adat Samin di Kabupaten Bojonegoro. Namun hanya variable (SOC) yang berpengaruh secara signifikan dengan nilai p-value 0.007 dan odds ratio 4.446 yang lebih besar dari 1,00. Hal ini mendukung Teori Kotler yang menyatakan bahwa perilaku nasabah dipengaruhi oleh faktor budaya, faktor sosial, faktor pribadi, dan faktor psikologis. Keputusan pembelian dari seorang nasabah sangat dipengaruhi oleh faktor kebudayaan. Kotler (2002 1:183)

Berdasarkan hasil regresi diketahui bahwa variabel Budaya (CULT) berpengaruh positif namun tidak signifikan terhadap Preferensi Perbankan Syariah Komunitas Adat Samin di Kabupaten Bojonegoro (PREF). Hal ini ditunjukkan dengan nilai variabel Budaya (CULT) sebesar 0.971 yang lebih besar dari $\alpha=5 \%$, sehingga $\mathrm{H}_{\mathrm{a}}$ ditolak atau $\mathrm{H}_{0}$ diterima.

Hasil regresi juga menunjukkan bahwa variabel Tingkat Pengetahuan (KNOW) berpengaruh positif namun tidak signifikan terhadap Preferensi Perbankan Syariah Komunitas Adat Samin di Kabupaten Bojonegoro (PREF) dengan nilai Tingkat Pengetahuan (KNOW) sebesar 0.393 lebih besar dari $\alpha=5 \%$, sehingga $\mathrm{H}_{\mathrm{a}}$ ditolak atau $\mathrm{H}_{0}$ diterima.

Hasil analisis penelitian ini tidak mendukung teori Kotler yang menyatakan bahwa Faktor kebudayaan merupakan faktor penentu yang paling dasar dari keinginan dan perilaku seseorang karena berdasarkan hasil regresi statistik variabel Budaya (CULT) mempunyai pengaruh positif namun tidak signifikan. Hasil Penelitian menunjukkan bahwa Faktor Sosial (SOC) yang berpengaruh secara signifikan. 
Hasil analisis yang menyatakan bahwa Faktor Sosial (SOC) berpengaruh signifikan terhadap Preferensi Perbankan Syariah di Kabupaten Bojonegoro dibuktikan dengan adanya temuan adanya enyelenggaraan arisan di Komunitas Adat Samin yang bebas dari sentuhan kapitalis yang identik dengan riba. Tradisi gotong royong ini mirip dengan prinsip mudharabah mutlaqah dalam keuangan syariah seperti deposito mudharabah. Berdasarkan prinsip ini, tidak ada batasan bagi bank untuk menggunakan dana yang dihimpun. (Muhammad, 2007: 179). Kegiatan Ekonomi yang bersifat sosial yang menerapkan sistem keuangan anti riba mendukung sistem Perbankan Syariah yang menerapkan prinsip anti riba. Hal ini yang menyebabkan Komunitas Adat Samin di Kabupaten Bojonegoro berminat untuk menjadi Nasabah Bank Syariah. Menurut Kotler (2002 1:183), "Perilaku nasabah dipengaruhi oleh faktor budaya, faktor sosial, faktor pribadi, dan faktor psikologis".

\section{KESIMPULAN DAN SARAN}

\section{Kesimpulan}

Berdasarkan pemaparan di atas dapat disimpulkan sebagai berikut;

1. Merujuk pada hasil regresi pada tabel 4.4 diketahui bahwa hasil analisis multivariat ketiga variabel (SOC, CULT, KNOW) berpengaruh positif terhadap Preferensi Perbankan Syariah Komunitas Adat Samin di Kabupaten Bojonegoro. Hanya variable (SOC) yang berpengaruh secara signifikan dengan nilai $p$-value 0.007 dan mempunyai odds ratio 4.446 lebih besar dari 1,00.

2. Berdasarkan hasil regresi diketahui variabel Budaya (CULT) berpengaruh positif namun tidak signifikan terhadap Preferensi Perbankan Syariah Komunitas Adat Samin di Kabupaten Bojonegoro (PREF). Hal ini ditunjukkan oleh nilai dari probabilitas variabel Budaya (CULT) sebesar 0.971 lebih besar dari $\alpha=5 \%$, sehingga $\mathrm{H}_{\mathrm{a}}$ ditolak atau $\mathrm{H}_{0}$ diterima.

3. Berdasarkan hasil regresi juga diketahui bahwa variabel Faktor Tingkat Pengetahuan (KNOW) mempunyai pengaruh positif namun tidak signifikan terhadap Preferensi 


\section{JURNAL \\ ANALISIS, PREDIKSI, DAN INFORMASI}

Perbankan Syariah Komunitas Adat Samin di Kabupaten Bojonegoro (PREF). Hal ini ditunjukkan oleh nilai dari probabilitas variabel Faktor Tingkat Pengetahuan (KNOW) sebesar 0.393 lebih besar dari $\alpha=5 \%$, sehingga $\mathrm{H}_{\mathrm{a}}$ ditolak atau $\mathrm{H}_{0}$ diterima.

4. Hasil analisis penelitian ini tidak mendukung teori Kotler yang menyatakan bahwa Faktor kebudayaan merupakan faktor penentu yang paling dasar dari keinginan dan perilaku seseorang karena berdasarkan hasil regresi statistik variabel Budaya (CULT) mempunyai pengaruh positif namun tidak signifikan. Hasil Penelitian menunjukkan bahwa Faktor Sosial (SOC) yang berpengaruh secara signifikan.

5. Hasil analisis yang menyatakan bahwa Faktor Sosial (SOC) berpengaruh signifikan terhadap Preferensi Perbankan Syariah di Kabupaten Bojonegoro dibuktikan dengan adanya temuan adanya penyelenggaraan arisan di Komunitas Adat Samin yang bebas dari sentuhan kapitalis yang identik dengan riba. Tradisi gotong royong ini mirip dengan prinsip mudharabah mutlaqah dalam keuangan syariah. Penerapan mudharabah mutlaqah bisa dalam bentuk tabungan dan deposito sehingga ada dua jenis penghimpunan dana yaitu deposito mudharabah dan mudharabah. Berdasarkan prinsip ini, tidak ada batasan bagi bank untuk menggunakan dana yang dihimpun. (Muhammad, 2007: 179). Kegiatan Ekonomi yang bersifat sosial yang menerapkan sistem keuangan anti riba mendukung sistem Perbankan Syariah yang menerapkan prinsip anti riba. Hal ini yang menyebabkan Komunitas Adat Samin di Kabupaten Bojonegoro berminat untuk menjadi Nasabah Bank Syariah. Menurut Kotler (2002 1:183), "Perilaku nasabah dipengaruhi oleh faktor budaya, faktor sosial, faktor pribadi, dan faktor psikologis". Keputusan nasabah dalam memilih produk perbankan dapat dipengaruhi faktor sosial, budaya maupun pribadi serta psikologi dari nasabah tersebut. Perilaku seorang nasabah dipengaruhi oleh faktor-faktor sosial seperti keluarga, kelompok acuan, serta peran dan status. Kelompok acuan seseorang adalah semua kelompok yang memiliki pengaruh langsung (tatap muka) atau tidak langsung terhadap sikap atau perilaku seseorang. 


\section{Saran}

1. Hasil analisis yang menyatakan bahwa Faktor Sosial (SOC) berpengaruh signifikan terhadap Preferensi Perbankan Syariah di Kabupaten Bojonegoro dibuktikan dengan adanya temuan adanya penyelenggaraan arisan di Komunitas Adat Samin yang bebas dari sentuhan kapitalis yang identik dengan riba. Berdasarkan temuan ini penulis berharap untuk pengembangan jaringan, Perbankan Syariah hendaknya lebih memperluas cakupan target sosialisasi untuk memperkenalkan produknya mengingat masih banyak komunitas-komunitas dengan skala besar memiliki minat dan antusisasme yang tinggi untuk menjadi Nasabah Bank Syariah.

2. Agar dapat memperoleh hasil penelitian yang lebih valid dan komprehensif maka penulis menyarankan agar Penelitian berikutnya diharapkan menggunakan data yang lebih akurat dengan jumlah sebaran dan konfigurasi yang lebih banyak karena dengan menggunakan data yang lebih akurat memungkinkan hasil yang lebih baik. menggunakan metode dan alat uji yang lebih lengkap dan akurat sehingga diperoleh kesimpulan yang lebih valid

\section{DAFTAR PUSTAKA}

Adiseputra, Yudhistira et al (2019), "Risk Analysis and Efficiency Islamic Banking: Evidence in Indonesia”. IKONOMIKA. Vol.4. No.2, hal. 151170.

American Marketing Association (AMA) yang dikutip oleh Philip Kotler dan Keller Kevin Lane yang diterjemahkan oleh Bob Sabran. 2009.

Agus Widarjono. 2010. Analisis Statistika Multivariat Terapan. Edisi pertama. Yogyakarta: UPP STIM YKPN

Anggadwipa dkk. 2013. Analisis Faktor-faktor Yang Mempengaruhi Nasabah (Mahasiswa) Dalam Memilih Menabung Pada Bank Syariah. PESAT (Psikologi, Ekonomi, Sastra, Arsitektur \& Teknik Sipil) Vol. 5 Oktober 2013

Anshori, Abdul G. 2007. Perbankan Syariah di Indonesia. UGM Press: Yogyakarta 


\section{JURNA \\ ANALISIS, PREDIKSI, DAN INFORMASI}

Antonio, M.Syafi'I. 2001. Bank Syariah Dari Teori Ke Praktek. Gema Insani Press: Jakarta

Alamsyah.(2015). Eksistensi dan Nilai-Nilai Kearifan Komunitas Samin di Kudus dan Pati. Jurnal Ilmu Budaya, vol. 21, issue 1, pp. 63-74.

Badriyah, N., Siswanto, S., \& Ishaq, I. (2020). Strategi Relational Benefit Terhadap Peningkatan Kepuasan Pelanggan Pada Alvira Mart Tikung Lamongan. Jurnal Sains Sosio Humaniora, 4(1), 189-193.

Arikunto, S. (2010). Prosedur penelitian: Suatu Pendekatan Praktik. (Edisi Revisi). Jakarta: Rineka Cipta.

Bank Indonesia. 2008. Undang-Undang No. 21 Tahun 2008: tentang Perbankan Syariah. Jakarta

Bank Indonesia. 2011. Peraturan No.13/23/PBI/2011: tentang Penerapan Manajemen Risiko Untuk BUS Dan UUS. Jakarta

Davidoff, L.L., (1981). Introduction to Psychology. McGraw-Hill, International Book Company, International Student Edition : Tokyo

Departemen Perbankan Syariah Otoritas Jasa Keuangan. 2020. Roadmap Perbankan Syariah Indonesia 2015-2019. Disseminasi Publikasi Laporan OJK. Yogyakarta.

DJ, Y. R. (2018). PENGARUH FAKTOR KEBERSIHAN, PENERANGAN DAN PERALATAN PRODUKSI TERHADAP PRODUKTIVITAS KARYAWAN PADA CV SINAR BADJA ELECTRIC DI SURABAYA. JPIM (Jurnal Penelitian Ilmu Manajemen), 3(3), 747-822.

DJ, Y. R. (2020). PENGARUH KETERAMPILAN DAN ETOS KERJA TERHADAP PRODUKTIVITAS KERJA PADA CV MANDIRI TRANS DI SURABAYA. Media Mahardhika, 19(1), 16-20.

Ghozali. I. 2006. Aplikasi Analisis Multivariate Dengan Program SPSS. Edisi II. Badan Penerbit Universitas Diponegoro. Semarang.

Hardiansyah, H. (2012). Metodologi Penelitian Kualitatif Untuk Ilmu-Ilmu Sosial. (3rd ed.). Jakarta: Selemba Humanika

Hasan, Iqbal. 2006. Analisis Data Penelitian Dengan Statistik. Jakarta: PT Bumi Aksara.

Ike Sulaili Sofiyanti and Puji Handayati, (2020), "Etnomethodologi Analysis of Syari'a Manifestation in the Samin Tribe's" in International Conference on Islam, 


\section{JURNAL

Economy, and Halal Industry, KnE Social Sciences, pages 269-280. DOI 10.18502/kss.v4i9.7331

Kotler, Philip. 1997. Manajemen Pemasaran 1: Analisis, Perencanaan, Implementasi dan Kontrol. Jakarta: Prenhallindo.

Kotler, Philip. 2002. Manajemen Pemasaran, Edisi Millenium, Jilid 2. Jakarta: PT Prenhallindo

Kotler, Philip dan Gary Amstrong, 2003, Marketing An Introduction, sixth edition, Upper Saddle River, New Jersey: Prentice Hall.

Kuncoro, Mudrajad. 2009. Metode Riset Untuk Bisnis dan Ekonomi. Jakarta: Erlangga.

Lubis, Z., Setiyawan, H., \& Mukhadiroh, L. (2019). The Effect Of Consumer Motivation, Quality Perception, And Consumer Attitude To The Decision Of Purchase Of Honda Brand Motorcycle IN Lamongan district: The Effect Of Consumer Motivation, Quality Perception, And Consumer Attitude To The Decision Of Purchase Of Honda Brand Motorcycle IN Lamongan district. Jurnal Mantik, 3(3), 157-161.

Lubis, Z., Mauladi, K. F., \& Irawan, M. R. N. (2020). PENENTUAN STRATEGI PEMASARAN DALAM MEMPERTAHANKAN EKSISTENSI DAN MENGADAPI PERSAINGAN (Studi Kasus Pada Gemilang Art Glass Di Modo). Media Mahardhika, 19(1), 59-70.

Muhammad. (2007). Pengantar Akuntansi Syariah (2nd ed.). Jakarta: Salemba Empat.

Munawaroh, Siti et al. 1995. Etnografi Masyarakat Samin di Bojonegoro. Balai Pelestarian Nilai Budaya (BPNB) Yogyakarta. Yogyakarta.

Moskowitz, M.J., and Orgel, A.R., (1969). General Psychology : A Core Text in Human Behavior. Boston: Houghton Mifflin Company.

Nazir, Moh. 2005. Metode Penelitian. Bogor: Ghalia Indonesia.

Permatadeny, Ary Nevita dan Zainal Arifin.2015. Perilaku, Karakterisitik, Persepsi Masyarakat Terhadap Bank Syariah di Eks Karesidenan Kediri. Jurnal Nusantara of Research Universitas Nusantara PGRI Kediri Volume 02. No.02, Oktober 2015

Rosyid, M. (2012). Perkembangan Komunitas Samin Di Kudus dan Perlawanannya Terhadap Program Pembangunan Irigasi Tahun 1986. (Thesis, Semarang, 2012). 


\section{JURNAAL \\ ANALISIS, PREDIKSI, DAN INFORMASI}

Saputra, Dwi Angga et al. 2016. Analisis Pengaruh Pendidikan dan Faktor Sosial terhadap Pengetahuan Masyarakat Tentang Bank Syariah. Jurnal Ekonomi Syari'ah Indonesia. Vol VI, No.1:12-22

Sari Y, Sumarwan U, Hosen N. 2015. Analisis Faktor-Faktor Preferensi Etnis Tionghoa Terhadap Bank Syariah di Indonesia. Jurnal Al-Muzara'ah, Vol. 3, No. 1 Juni 2015 Institut Pertanian Bogor

Siregar, Mulya.Agenda Pengembangan Perbankan Syariah Untuk Mendukung Sistem Ekonomi yang Sehat di Indonesia : Evaluasi, Prospek, dan Arah Kebijakan. IQTISAD Journal of Islamic Economics ISSN 1411 - 013X Vol. 3, No. 1, Muharram 1423 H/Maret 2002 pp. 46-66

Tjiptono, Fandy dan Gregorius Candra. 2008. Service Quality Dan Statisfaction. Yogyakarta: Andi.

Tjiptono, Fandy. 2000. Manajemen Jasa. Yogyakarta : Andi. Tjiptono, Fandy. 2008. Strategi Pemasaran. Edisi 3. P.3.

Woodworth, R.S.and Marquis, D.G. (1957). Psycholog.Henry Holt and Company,New York

Yunus, H. S. 2010. Metodologi Penelitian Wilayah Kontemporer. Pustaka Pelajar. Yogyakarta.

Wawancara Kepala Desa Margomulyo Bpk. Nuryanto Tanggal 14 September 2020 di Kecamatan Margomulyo

Wawancara Koordinator Komunitas Adat Samin Dusun Jepang Bpk. Bambang Sutrisno Tanggal 14 September 2020 di Kecamatan Margomulyo 